УДК 332.142.2

\title{
ТЕОРЕТИКО-ЕКОНОМІЧНІ АСПЕКТИ ВИЗНАЧЕННЯ СОЦАЛЬНОЇ БЕЗПЕКИ РЕГІОНІВ УКРАЇНИ
}

\author{
Александрова О.Ю., к.е.н., доцент, \\ Косич М.В., к.е.н., доцент, \\ Фролов О.І., к.е.н., доцент (УкрДУЗТ)
}

В умовах переходу до ринкових відносин важливу роль повинна відігравати сочіальна політика держави. Соціальна безпека визначається наявністю такого стану розвитку суспільних відносин, який би надав можливість громадянам задовольнити свої потреби на достатньому рівні. Досягнення оптимальної ситуаиії в даній сфері можливе лише в результаті ијілеспрямованих дій стосовно основних складових соиіальної політики, політичних завдань і можливостей вітчизняної економіки.

Ключові слова: соціальна безпека, соціальна політика, коефіцієнт соціальної безпеки, соціальна безпека держави, соціальна безпека регіонів.

\section{ТЕОРЕТИКО-ЭКОНОМИЧЕСКИЕ АСПЕКТЫ ОПРЕДЕЛЕНИЯ СОЦИАЛЬНОЙ БЕЗОПАСНОСТИ РЕГИОНОВ УКРАИНЫ}

\author{
Александрова Е.Ю., к.э.н., доцент, \\ Косич М.В., к.э.н., доцент, \\ Фролов А.И., к.э.н., доцент (УкрГУЖТ)
}

В условиях перехода к рыночным отношениям важную роль должна играть сочиальная политика государства. Социальная безопасность определяется наличием такого состояния развития общественных отношений, которое бы предоставило возможность гражданам удовлетворить свои потребности на достаточном уровне. Достижение оптимальной ситуации в данной сфере возможно только в результате целенаправленных действий по основным составляющих сочиильной политики, политических заданийч и возможностей отечественной экономики.

Ключевые слова: социальная безопасность, социальная политика, коэффициент социальной безопасности, социальная безопасность государства, социальная безопасность регионов.

\section{THEORETICAL AND ECONOMIC ASPECTS OF DETERMINING THE SOCIAL SECURITY OF THE REGIONS OF UKRAINE}

\author{
Alekcandrova H., PhD (Econ.), associate professor, \\ Kosych M., PhD (Econ.), associate professor, \\ Frolov A., PhD (Econ.), associate professor (USURT)
}

In the context of transition to market relations in order to ensure social stability and social coherence, the social policy of the state should play an important role. At the present stage of development of our country there is an increase in social tensions in society, a decrease in the well-being of the population and an accumulation of social problems. The increase in

(C) Александрова О.Ю.,

Косич М.В.,

Фролов О.І.
Вісник економіки транспорту і промисловості № 68, 2019 
social problems poses a threat to national security, which can cause disruption to the equilibrium and stability of Ukraine's economy.

In our opinion, social security is determined by the existence of such a state of development of social relations (material-everyday, housing-communal, socio-cultural), which would enable citizens to satisfy their current and future needs in them at a sufficient level, to offset the impact of threats. Achieving an optimal situation in this field is possible only as a result of deliberate action on the main components of social policy, political objectives and opportunities of the domestic economy. The main components of social policy that determine the level of social security include: the level of income of the population, wages, employment, demographic situation, socio-class differentiation.

Despite the steady rise in nominal wages, real wages did not have a steady rise. Despite the relatively high employment rate in Ukraine, its indicators tend to decline. During 2010 2018, there was a negative population growth. On the basis of comparison of actual and threshold values of social security of the state and regions, as well as tendencies of its development, a situational analysis of the state of social security of Ukraine in the regional dimension was conducted. This made it possible to identify strengths, weaknesses, opportunities and security threats. In order to improve the situation regarding the provision of social security of the state and the regions, the following provisions should be implemented: increase of state funding of social development programs; creation of new and improvement of existing working conditions of the population; improving the social process management system at the regional level; development of effective programs for providing housing, education, culture, medicine to the population.

Keywords: social security, social policy, coefficient of social security, social security of the state, social security of regions.

Постановка проблеми. В умовах переходу до ринкових відносин з метою забезпечення соціальної стабільності та суспільної злагоди важливу роль повинна відігравати соціальна політика держави. Метою іiі реалізації виступає задоволення інтересів і потреб громадян у сфері праці, освіти, культури, охорони здоров'я, забезпечення житлом, торгового i побутового обслуговування та відпочинку. На сучасному етапі розвитку нашої країни спостерігається посилення соціальної напруженості у суспільстві, зниження добробуту населення та накопичення соціальних проблем. Зростання соціальних проблем створює загрозу національній безпеці, що може стати причинами порушення рівноваги та стабільності економіки України.

Аналіз останніх досліджень та публікацій. Основні теоретико-економічні та практичні питання забезпечення соціальної безпеки розглянуті в роботах таких вчених, як В. Скуратівський [1], О.
Новікова [2], О.Білорус [3], В.Паламарчук [4], Л.Весельська [5] .

Виділення невирішених частин загальної проблеми. В нашій країні не визначена та не створена нормативноправова база державного регулювання та забезпечення соціальної безпеки, бо дослідження у цій сфері пов'язані тільки із національною безпекою в цілому.

Метою статті $\epsilon$ оцінка сильних та слабких сторін соціальної безпеки України для виявлення iї можливостей та загроз.

Виклад основного матеріалу дослідження. Існують різноманітні визначення суті поняття соціальної безпеки українськими вченими.

О. Новікова визначає, що соціальна безпека - це стан захищеності соціальних інтересів особи і суспільства від впливу загроз національній безпеці, що є наслідком реалізації заходів соціального захисту, який характеризує їх результативність та ефективність[2, с. 17].

B. Скуратівський говорить, що 
соціальна безпека $є$ складова національної безпеки, шо визначає стан захищеності життєво важливих інтересів суспільства, держави від внутрішніх та зовнішніх загроз, а також від загрози соціальним інтересам $[1$, c. 306$]$.

О. Білорус трактує поняття «соціальна безпека» так - надійна захищеність життєво важливих інтересів соціальних суб'єктів на макро- та мікрорівнях, збереження i розвиток людського потенціалу, підтримка ефективного стимулювання діяльності людей, систем їхньої соціалізації та життєзабезпечення, невмирущих цінностей, моральності [3, с. 105].

В. Паламарчук розглядає соціальну безпеку як недопущення умов, які сприяли неприйнятному зниженню рівня життя верств населення i окремих соціальних груп, що обумовлює соціальну деградацію, а також забезпечення умов збереження соціальної перспективи для всіх прошарків населення [4, с. 216].

Л. Весельська соціальна безпека позитивно врегульований правовими нормами і реалізований на практиці стан, коли держава забезпечує наявними в іiі розпорядженні демократичними методами управління гідний рівень життя громадян та гарантує задоволення належних потреб іiі розвитку [5, с. 567].

На нашу думку, соціальна безпека визначається наявністю такого стану розвитку суспільних відносин (матеріальнопобутових, житлово-комунальних, соціально-культурних), який би надав можливість громадянам задовольнити свої поточні та перспективні потреби в них на достатньому рівні, нівелювати вплив загроз. Досягнення оптимальної ситуації в даній сфері можливе лише в результаті цілеспрямованих дій стосовно основних складових соціальної політики, політичних завдань i можливостей вітчизняної економіки. До основних складових соціальної політики, які визначають рівень соціальної безпеки належать: рівень доходів населення, оплата праці, зайнятість, демографічна ситуація, соціально-класова диференціація.

Не зважаючи на постійне зростання номінальної заробітної (протягом 2010 2018 рр. вона зросла більш ніж на 123 \%), реальна заробітна плата не мала стабільного зростання. Її скорочення спостерігалося у 2009, 2014 та 2015 рр., а у 2018 році темпи зростання впали порівняно 3 попередніми двома роками. В ті роки, коли було зростання реальної заробітної плати, темпи іiі зміни були нижче ніж номінальної заробітної плати - протягом 2010 - 2018 рр. вона зросла лише на $99 \%$.

Для розрахунку коефіцієнтів соціальної безпеки держави і регіонів за досліджуваний період (2010 - 2018 рр.) було враховано вплив як стимулюючого компоненту (показники-стимулятори), так і дестимулюючого (показникидестимулятори). До показниківстимуляторів було віднесено 8 індикаторів: середньомісячна заробітна плата, грошові доходи населення, кількість зайнятого населення, забезпеченість населення житлом, забезпеченість вчителями середніх шкіл, книжковий фонд бібліотек, кількість місць у закладах культури клубного типу, кількість лікарняних ліжок. Значна кількість показників-стимуляторів не мала зростання, що являється несприятливим процесом, так як свідчить про наявність дестабілізуючих процесів в соціальній сфері держави та регіонів [6]. Показникидестимулятори представлені наступними: кількість безробітного населення, навантаження на одне вільне робоче місце, заборгованість із заробітної плати.

Розрахунки коефіцієнтів соціальної безпеки були проведені на основі статистичних матеріалів Державного комітету статистики України [6] та Міністерства економіки України [7]. Для визначення значень коефіціснтів соціальної безпеки регіонів був використаний індексний метод. Результати дослідження наведено у таблиці 1.

Як свідчать отримані дані, коефіцієнт соціальної безпеки України не 
має стабільного характеру. Максимальне значення він мав у середині минулого десятиріччя. Даний показник $\epsilon$ результатом впливу стимулюючого та дестимулюючого компонентів.

Слід зазначити, що у 2010 р. більш активними були стимулюючі компоненти, а у 2015 та 2018 роках на рівень соціальної безпеки вплинули де стимулюючи компоненти.

Аналіз коефіцієнтів у 2010 році демонструє лідерство за Донецькою та Луганською областями, які нажаль $\mathrm{y}$ наступні роки втратили ці позиції.
В регіональному вимірі найвищими значеннями коефіцієнтів соціальної безпеки у 2015 році характеризувалися Хмельницька, Закарпатська, Чернівецька області та м. Київ. Існування високих значень коефіцієнтів безпеки пояснюється сприятливою соціальною ситуацією на їх територіях. На відміну від цих регіонів, мінімальні величини були притаманні Луганської, Донецької, Кіровоградської та Чернігівської областям. У 2018 році ситуація залишилася майже не змінною порівняно з 2015 роком.

Таблиия 1

Сочіальна безпека регіонів України

\begin{tabular}{|l|c|c|c|}
\hline Область & 2010 & 2015 & 2018 \\
\hline Вінницька & 0,321 & 0,443 & 0,458 \\
\hline Волинська & 0,344 & 0,402 & 0,412 \\
\hline Дніпропетровська & 0,531 & 0,484 & 0,502 \\
\hline Донецька & 0,864 & 0,391 & 0,345 \\
\hline Житомирська & 0,311 & 0,472 & 0,481 \\
\hline Закарпатська & 0,261 & 0,611 & 0,732 \\
\hline Запорізька & 0,381 & 0,428 & 0,501 \\
\hline Івано-Франківська & 0,298 & 0,533 & 0,675 \\
\hline Київська & 0,284 & 0,541 & 0,586 \\
\hline Кіровоградська & 0,281 & 0,354 & 0,433 \\
\hline Луганська & 0,542 & 0,316 & 0,302 \\
\hline Львівська & 0,427 & 0,473 & 0,498 \\
\hline Миколаївська & 0,297 & 0,428 & 0,445 \\
\hline Одеська & 0,381 & 0,532 & 0,634 \\
\hline Полтавська & 0,331 & 0,378 & 0,411 \\
\hline Рівненська & 0,286 & 0,455 & 0,521 \\
\hline Сумська & 0,283 & 0,400 & 0,423 \\
\hline Тернопільська & 0,278 & 0,419 & 0,526 \\
\hline Харківська & 0,421 & 0,508 & 0,611 \\
\hline Херсонська & 0,301 & 0,416 & 0,489 \\
\hline Хмельницька & 0,304 & 0,726 & 0,815 \\
\hline Черкаська & 0,302 & 0,407 & 0,513 \\
\hline Чернівецька & 0,245 & 0,702 & 0,848 \\
\hline Чернігівська & 0,271 & 0,382 & 0,442 \\
\hline Україна & 0,471 & 0,477 & 0,493 \\
\hline
\end{tabular}

Найнижчі значення цих регіонів зумовлюють формування непривабливого соціального середовища, що викликає відтік активних прошарків населення до інших територій держави. Внаслідок існування подібного явища зазначені регіони відчувають нестачу населення i трудових ресурсів для свого розвитку.

Не дивлячись на те, що в Україні зберігається досить високий рівень 
зайнятості - в середньому 65 \% населення працездатного віку, його показники мають тенденцію до зниження - 3 66,9 \% у 2012 році до 64,2 в 2016 році, у 2018 році цей показник зріс до 66,1\% [6].

Показник кількості зайнятого населення при значенні в 2010 р. у 17,45 млн. чол. до 2018 р. включно мав зменшення, і скоротився за цей час до 15,72 млн. осіб, тобто біля 1,7 млн. чол [6].

Аналіз регіонів України за питомою вагою показав, що максимальні величини притаманні тим, які мають значний праце ресурсний потенціал. В 2010 р. подібними регіонами були Донецька, Дніпропетровська і Харківська області. Ці регіони являються основними щодо зосередження потенціалу зайнятого населення. На відміну від зазначених, мінімальними були показники Чернівецької i Волинської областей. В число лідерів увійшли Дніпропетровська, Миколаївська, Харківська області, а аутсайдерами стали Луганська, Чернівецька та Кіровоградська області. У наступні роки значних коливань не спостерігалося, тобто і лідери, i аутсайдери залишилися тими ж самими [7].

В останні роки збільшується рівень безробіття серед молоді. Значними темпами зростає рівень безробіття у Донецької, Луганської, Чернігівської областях. Протягом всього періоду лише м. Київ характеризувалося сприятливим співвідношенням (недосягнення порогового значення). Не зважаючи на те, що його значення не досягають порогових, це свідчить про наявність соціальної напруги у суспільстві.

У 2010 pp. 19 суб'єктів (областей) iз 25 мали рівень доходів населення в розрахунку на одну особу нижче середнього значення по Україні, у 2015 році таких областей було вже 20 (80\%), а у 2018 p. - 18. Протягом всього періоду дослідження дохід нижче середнього мали Вінницька, Волинська, Житомирська, Закарпатська, Івано-Франківська, Кіровоградська, Луганська, Львівська, Миколаївська, Рівненська, Сумська,
Тернопільська, Херсонська, Хмельницька, Черкаська, Чернігівська області [7] .

Протягом 2010 - 2018 років спостерігався від'ємний приріст населення. У 2010 році населення скоротилося більш ніж на 200 тисяч осіб, у наступні роки цей показник мав позитивну тенденцію, тобто скорочувався аж до 2017 року, а потім знов стрімко почав зростати до зменшення населення більш ніж на 210 та 250 тисяч осіб у 2017 та 2018 роках відповідно. Скорочення населення в останні роки відбувається за рахунок зменшення народження дітей майже на $33 \%$ у 2018 році порівняно з 2010 роком [6].

Найгірші показники від'ємного приросту населення зафіксовані у Дніпропетровської, Луганської, Харківської, Чернігівської та Запорозької областях.

Проводячи аналіз розвитку соціальних процесів, економісти частіше всього звертаються до величини середньомісячної заробітної плати (СЗП), яка характеризує купівельну спроможність результатів праці робітника протягом одного робочого місяця [8, с. 95].

Згідно статистичної інформації темпи росту реальної заробітної плати були значно меншими ніж зростання номінальної заробітної плати за 2010- 2018 роки [6]. Традиційно реальна зарплата мали високі темпи зниження у 2014 та 2015 роках: 93,5 та 79,8 \% відповідно[6].

Необхідно зауважити стосовно величини середнього значення по державі та його співвідношення зі світовими характеристиками. За методологією $\mathrm{OOH}$ [9], межею бідності вважається отримання доходу 4 дол. США на добу на одну особу (або близько 120 дол. США на місяць). Згідно офіційного обмінного курсу НБУ, показник СЗП держави в доларовому еквіваленті склав у 2010 році - 289,0 \$, в 2015 p. - 161,3 \$, a y 2018 p. - 325\$ [6]. Серед 27 регіонів лише один (м. Київ) характеризується перевищенням світової межі бідності. Однак, в значній кількості регіонів спостерігається від'ємне 
відхилення навіть від середнього значення по Україні. Не дивлячись на те, що в країни спостерігається зменшення чисельності населення, у якого середньомісячний дохід нижче законодавчо встановленого прожиткового рівня з 8,6 \% у 2010 році до 1,3\% у 2018 році, однак дійсний рівень прожиткового мінімуму значно вищий за законодавчо встановлений, тому кількість населення, що отримує доходи менше фактично прожиткового мінімуму протягом останніх років зростає та у 2018 році складає 27,6 \% від усього населення [6].

Показник грошових доходів відображає весь сумарний прибуток, який отримує населення, що включає надходження грошей у вигляді оплати праці всім категоріям працюючих, пенсії, доходи від власності, стипендії та різні допомоги, надходження від продажу продуктів сільського господарства та іноземної валюти тощо [10, с. 185].

В структурі сукупних ресурсів населення спостерігається переважання заробітної плати і соціальної допомоги та інших одержаних поточних трансфертів (рисунок 1).

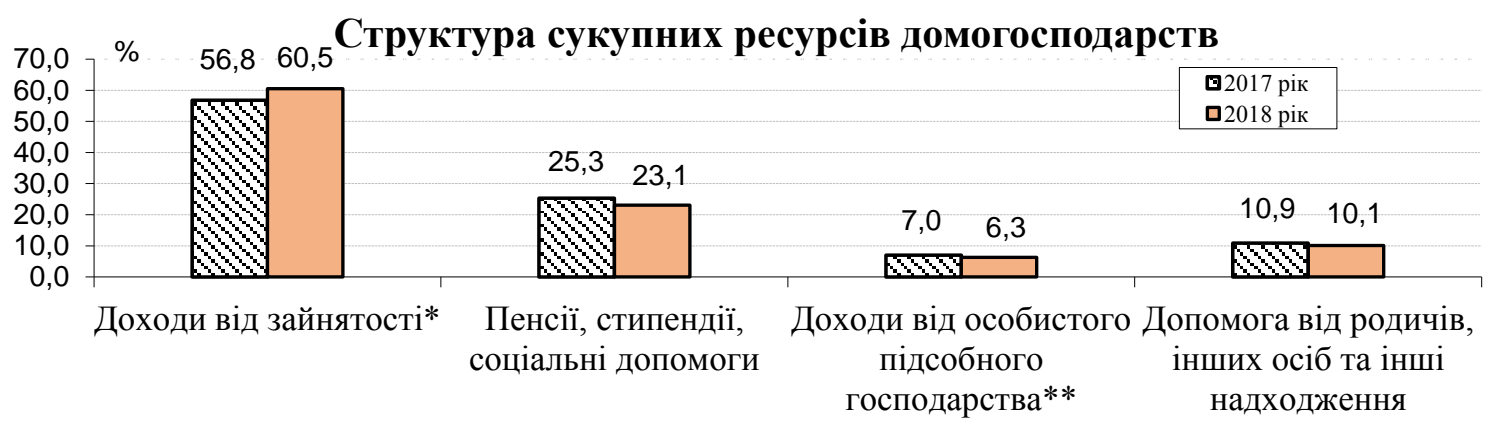

Рис. 1. Структура сукупних ресурсів населення, \%

Така структура не є прогресивною, так як зорієнтована на значну підтримку 3 боку держави i не передбачає вагомі надходження за рахунок використання власних джерел. В даному випадку проблема активізації власних джерел надходжень зумовлена i незадовільним розвитком фінансової та інвестиційної інфраструктури, умови функціонування якої не дозволяють населенню диверсифікувати структуру надходжень доходів [11, с. 114].

На основі співставлення фактичних i порогових значень соціальної безпеки держави і регіонів, а також тенденцій iї розвитку було проведено ситуаційний аналіз стану соціальної безпеки України в регіональному вимірі.

Це дало змогу визначити сильні i слабкі сторони, можливості i загрози безпеці (таблиця 2).

Висновки. 3 метою поліпшення ситуації стосовно забезпечення соціальної безпеки держави i регіонів необхідно реалізувати наступні положення: збільшення державного фінансування соціальних програм розвитку; створення нових та удосконалення існуючих умов праці населення; удосконалення системи управління соціальними процесами на регіональному рівні; розробка ефективних програм забезпечення населення житлом, закладами освіти, культури, медицини. 
Таблиия 2

Ситуаційний аналіз стану соиіальної безпеки Украӥни в регіональному вимірі за nepiod 2010-2018 pp.

\begin{tabular}{|c|c|}
\hline Сильні сторони & Слабкі сторони \\
\hline $\begin{array}{l}\text { 1. Зростання середньомісячної заробітної плати і } \\
\text { грошових доходів населення. } \\
\text { 2. Зменшення заборгованості з виплати заробітної } \\
\text { плати населенню. } \\
\text { 3. Наявність висококваліфікованого трудового } \\
\text { потенціалу, який є основою соціальної політики } \\
\text { держави. } \\
\text { 4. Відсутність різких динамічних коливань } \\
\text { показників соціальної безпеки. } \\
\text { 5. Зменшення пресингу на ринку праці в результаті } \\
\text { зниження навантаження на одне вільне робоче місце } \\
\text { для держави і регіонів. }\end{array}$ & $\begin{array}{l}\text { 1. Невідповідність фактичних значень показників } \\
\text { безпеки пороговим. } \\
\text { 2. Зростання кількості безробітного населення. } \\
\text { 3. Недостатнє фінансування соціального сектору з } \\
\text { боку держави. } \\
\text { 4. Динаміка показників розвитку освітянсько- } \\
\text { культурного сектору та охорони здоров’я є } \\
\text { недостатньою, що призводить до суттєвого зниження } \\
\text { рівня культурного і медичного забезпечення } \\
\text { населення. } \\
\text { 5. Рівень оплати праці, не дивлячись на існуюче } \\
\text { зростання, не є прийнятним за міжнародними } \\
\text { стандартами. } \\
\text { 6. Значна диференціація в оплаті праці }\end{array}$ \\
\hline Можливості & Ризики загроз \\
\hline $\begin{array}{l}\text { 1. Збереження існуючих темпів зростання показників } \\
\text { середньомісячної заробітної плати і грошових } \\
\text { доходів населення. } \\
\text { 2. Поліпшення соціального клімату в державі, } \\
\text { удосконалення системи просторового розподілу } \\
\text { трудових ресурсів. } \\
\text { 3. Оптимізація розвитку соціальної інфраструктури в } \\
\text { регіональному вимірі. }\end{array}$ & $\begin{array}{l}\text { 1. Втрати трудового потенціалу держави, зниження } \\
\text { рівня його кваліфікації. } \\
\text { 2. Збільшення розриву між номінальної та реальної } \\
\text { заробітної платою. } \\
\text { 3. Посилення відтоку працездатного населення } \\
\text { (особливо молоді) за межі держави. } \\
\text { 4. Зростання невдоволеності населення соціальною і } \\
\text { економічною ситуацією. } \\
\text { 5. Тенізація економіки та заробітної плати }\end{array}$ \\
\hline
\end{tabular}

ПЕРЕЛІК ВИКОРИСТАНИХ ДЖЕРЕЛ

1. Скуратівський В.А. Управління соціальним i гуманітарним розвитком [Текст]: навчальний посібник / В. А. Скуратівський, В. П. Трощинський та ін. К.: НАДУ, 2009. - Ч. 1. - 456 с.

2. Новікова О.Ф. Соціальна безпека: теорія та українська практика [Текст]: монографія / I. Ф. Гнибіденко, А. М. Колот, О. Ф. Новікова В. В. Рогового. - К.: КНЕУ, 2006. - 292 c.

3. Білорус О.Г. Глобалізація та безпека розвитку [Текст]: монографія / О.Г. Білорус, Д.Г. Лук'яненко та ін. - К.: Вид-во КНЕУ, 2001. - 733 с.

4. Предборський В. А. Економічна безпека держави [Текст]: монографія / В.А. Предборский - К.: Кондор, 2005. $391 \mathrm{c}$.

5. Кальницька М.А. Соціальна безпека: поняття та рівні дослідження [Текст] / М.А. Кальницька // Демографія, економіка праці, соціальна економіка i політика. - 2017. - випуск 17. - С. 566-571.

6. http://www.ukrstat.gov.ua/

7. http://www.me.gov.ua/

8. Стан та перспективи соціальної безпеки в Україні: експертні оцінки [Текст]: монографія / О. Ф. Новікова, О. Г. Сидорчук, О. В. Панькова [та ін.] / Львівський регіональний інститут державного управління НАДУ; НАН України, Інститут економіки промисловості . - К. ; Львів : ЛРІДУ НАДУ, 2018. - 184 с.

9. Соціально-економічна захищеність населення України: Статистичне видання. - К.: ІВЦ Держкомстату України, 2013. $150 \mathrm{c}$.

10. Стратегія i тактика, стан соціально-економічного розвитку України: наук.-інф. зб. / за заг. ред. В. П. Горбуліна. - Науковий центр 3 питань євроатлантичної інтеграції України. - К.: Свроатлантікінформ, 2006. - 385 с.
11. Третяк
В. П. Державне 
регулювання інноваційних відносин у соціальній сфері / В. П. Третяк // Вісник Харківського національного університету iм. В. Н. Каразіна. Серія : економічна. 2010. - № 921. - С. 111 - 116. - Режим доступу: http://nbuv.gov.ua/ UJRN/VKhE_2010_921_21.

\section{REFERRENCES}

1. Skurativskyi V.A.

(2009)

Upravlinnia sotsialnym $i$ humanitarnym rozvytkom [Management of social and humanitarian development]. Kyiv: NADU. (in Ukrainian)

2. Novikova O.F. (2006) Sotsialna bezpeka: teoriia ta ukrainska praktyka [Social Security: Theory and Ukrainian Practice]. Kyiv: KNEU. (in Ukrainian)

3. Bilorus

O.H.

(2001)

Hlobalizatsiia ta bezpeka rozvytku [Globalization and security of development]. Kyiv: KNEU. (in Ukrainian)

4. Predborskyi V.

A. (2005)

Ekonomichna bezpeka derzhavy [Economic security of the state]. Kyiv: Kondor. (in Ukrainian)

5. Kalnytska M.A. (2017) Sotsialna bezpeka: poniattia ta rivni doslidzhennia [Social Security: Concepts and Levels of Research]. Demography, Labor Economics,
Social Economics and Politics, vol. 17, pp. 566-571.

6. http://www.ukrstat.gov.ua/

7. http://www.me.gov.ua/

8. O. F. Novikova, O. H. Sydorchuk, O. V. Pankova (2018) Stan ta perspektyvy sotsialnoi bezpeky $v$ Ukraini: ekspertni otsinky [Social security status and prospects in Ukraine: expert assessments]. Lviv : LRIDU NADU. (in Ukrainian)

9. Derzhavna sluzhba statystyky Ukrainy (2013) Sotsialno-ekonomichna zakhyshchenist naselennia Ukrainy: Statystychne vydannia [Socio-economic protection of the population of Ukraine: Statistical edition], Kyiv: IVTs Derzhkomstatu Ukrainy.

10. Horbulina V. P. (2006) Stratehiia $i$ taktyka, stan sotsialno-ekonomichnoho rozvytku Ukrainy [Strategy and tactics, state of socio-economic development of Ukraine]. Kyiv: Yevroatlantikinform. (in Ukrainian)

12. Tretiak V. P. (2010) Derzhavne rehuliuvannia innovatsiinykh vidnosyn $\mathrm{u}$ sotsialnii sferi [State regulation of innovative relations in the social sphere]. Visnyk Kharkivskoho natsionalnoho universytetu im. V. N. Karazina. Seriia: ekonomichna (electronic journal), no. 921, pp. 111 - 116. Available at: http://nbuv.gov.ua/ UJRN/VKhE_2010_921_21 (accessed 21 november 2019).

УДК 33:004

\title{
О ВЛИЯНИИ ЦИФРОВОЙ РЕВОЛЮЦИИ НА ЭКОНОМИКУ И ЧЕЛОВЕКА: ЭФФЕКТЫ ЦИФРОВИЗАЦИИ
}

\author{
Компаниец В. В., д.э.н, профессор (УкрГУЖТ),
}

Крацер В. В., к.э.н., вед. экономист по труду (ООО «Нью Системс АМ» Межнународный аэропорт Харьков)

В статье мы показали, что «цифровая революиия» мало повлияла на развитие экономики.

Расходы на ИКТ в мире в иелом представляют собой огромные суммы и растут быстрее, чем ВВП. При этом ИКТ способствуют экономическому росту только в условиях

(C) Компаниец В.В., Крацер В.В.

Вісник економіки транспорту і промисловості № 68, 2019 